\title{
The Dasyscyphins $A \sim C$ and Niveulone, New Biologically Active Compounds from the Ascomycete Dasyscyphus niveus
}

\author{
Viktor Mierau, Veronica Rojas de la Parra, Olov Sterner, Timm Anke
}

Received: September 21, 2005 / Accepted: December 27, 2005

(C) Japan Antibiotics Research Association

\begin{abstract}
In the course of a screening for cytotoxic compounds from fungi four new terpenoid metabolites, named dasyscyphins A, B, C, and niveulone were isolated from fermentations of Dasyscyphus niveus strain A0101. While dasyscyphin A (1) exhibited no significant biological activities in our test systems dasyscyphin B (2) and dasyscyphin C (3) showed cytotoxic activities against human (HepG2, Hela S3, U937, Colo-320, Jurkat) cell lines with $\mathrm{IC}_{50}$-values of $0.5 \sim 3 \mu \mathrm{g} / \mathrm{ml}$ while the activity of niveulone (4) was less pronounced. Only modest or weak antibiotic properties were observed for (2) and (3).
\end{abstract}

Keywords dasyscyphins A $\sim$ C, niveulone, Dasyscyphus niveus, cytotoxic activities

\section{Introduction}

Although Dasyscyphus species are very common and can be found almost everywhere on lignicolous substrates not much is known of their secondary metabolism and its products. From Dasyscyphella (Dasyscyphus) niveus SANK 26995 the antibacterial terpenoids F-12436 A, B, and $\mathrm{C}$ have been described in a patent [1]. From Dasyscyphus spp. bioactive cyclopentenones have been described recently [2]. Dasyscyphus mollissimus has been found to produce scyphostatin [3], a compound with diverse pharmacological activities. In the following we wish to describe the isolation and biological characterization of four new terpenoids from Dasyscyphus niveus strain A0101, of which two possess potent cytotoxic

T. Anke (Corresponding author), V. Mierau: Institute of Biotechnology and Drug Research IBWF, Erwin-Schrödinger-Str. 56, D-67663 Kaiserslautern, Germany,

E-mail: anke@rhrk.uni-kl.de activities. The elucidation of their structures is described elsewhere $[4,5]$.

\section{Materials and Methods}

Producing Organism

Dasyscyphus niveus strain A01-01 was isolated from spore prints of fruiting bodies found on a rose twig collected in Mannheim, Germany. The specimen showed all characteristics of the genus and the species. The strain was maintained at $4{ }^{\circ} \mathrm{C}$ on agar slants on yeast malt glucose medium (YMG) composed of ( $\mathrm{g} /$ liter): yeast extract (4), malt extract (10), glucose (4), and agar (15), pH 5.5. Mycelial cultures and herbarium material were kindly provided by $\mathrm{H}$. Anke and are deposited in the culture collection of the Institute of Biotechnology and Drug Research IBWF, Kaiserslautern.

\section{Fermentation and Isolation of Dasyscyphin A (1),}

Dasyscyphin B (2), Dasyscyphin C (3) and Niveulone (4) Fermentations were carried out in 20 liters of YMG medium in a Biolafitte $\mathrm{C} 6$ fermenter at $22^{\circ} \mathrm{C}$ with aeration (2.5 liters/minute) and agitation (120 rpm). A well-grown culture $(250 \mathrm{ml})$ in the same medium was used as inoculum, and the antibiotic activity was measured with samples withdrawn every day in the conventional agar diffusion assay using Nematospora coryli as test organism. After 9 days of fermentation when the antifungal activity had reached the maximum, the culture fluid was separated from the mycelia and passed through a column

V. Rojas de la Parra, O. Sterner: Department of Organic and Bioorganic Chemistry, University of Lund P.O.Box 124, S-22100 Lund, Sweden 

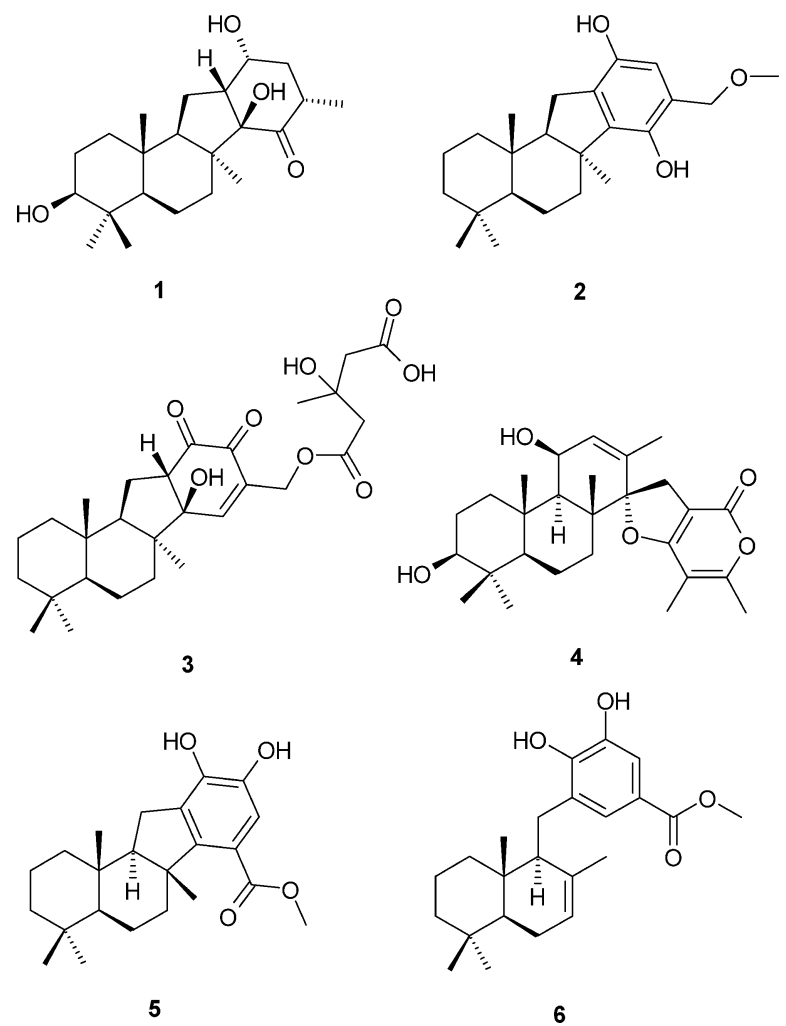

Fig. 1 Structures of dasyscyphin A (1), dasyscyphin B (2), dasyscyphin C (3), niveulone (4), pelorol (5), and smenodiol (smenospongin) (6).

$(30 \times 5.5 \mathrm{~cm})$ containing Mitsubishi Diaion HP 21 adsorber resin. The column was washed with water and the dasyscyphins and niveulone eluted with methanol. After removal of the solvent the crude product $(5.6 \mathrm{~g})$ was applied onto a column $(6 \times 2.5 \mathrm{~cm})$ containing Merck silica gel 60 . Elution with cyclohexane - ethyl acetate $1: 1$ yielded $584 \mathrm{mg}$ of a mixture containing 1, 2 and 3, and elution with $100 \%$ ethyl acetate yielded $500 \mathrm{mg}$ of crude niveulone (4). Final purification of 1, 2, and $\mathbf{3}$ was achieved by preparative HPLC (Jasco model PU-1587 with multiwavelength detector) on Nucleosil RP18 ( $7 \mu \mathrm{m}$; column $250 \times 21.2 \mathrm{~mm}$; flow $35 \mathrm{ml} /$ minute). Elution with water-methanol 39:61 $\mathrm{v} / \mathrm{v}$ yielded $14 \mathrm{mg}$ of dasyscyphin A (1), $5: 95 \mathrm{v} / \mathrm{v} 33 \mathrm{mg}$ of dasyscyphin C (3), 2:98 v/v $23 \mathrm{mg}$ of dasyscyphin B (2) (for structures see Fig. 1). Further purification of crude niveulone (4) by preparative HPLC on Nucleosil RP18 ( $7 \mu \mathrm{m}$; column $250 \times 21.2 \mathrm{~mm}$; flow $35 \mathrm{ml} /$ minute) with water - methanol $32: 68 \mathrm{v} / \mathrm{v}$ yielded $6 \mathrm{mg}$ of pure niveulone (4). Besides compounds $\mathbf{1} \sim \mathbf{4}$ the crude product $(5.6 \mathrm{~g}$ see above) contained $87 \mathrm{mg}$ of mycophenolic acid and $16 \mathrm{mg}$ of its methyl ester.

\section{Biological Assays}

HepG2 (DSMZ ACC 180, human hepatocellular carcinoma) and Hela S3 (ATCC CCL 2.2 human cervix carcinoma) cell lines were grown in DMEM-medium, and U937 (ATCC CRL-1593, human histocytic lymphoma), Colo-320 (DSMZ ACC-144 human colon adenocarcinoma) and Jurkat (ATCC TIB 152 human acute T cell leukemia) in RPMI medium supplemented with $10 \%$ of fetal calf serum. All media contained $65 \mu \mathrm{g} / \mathrm{ml}$ of penicillin $\mathrm{G}$ and $100 \mu \mathrm{g} / \mathrm{ml}$ of streptomycin sulfate. The cells $\left(\sim 10^{5} / \mathrm{ml}\right)$ were incubated in microtiter plates with or without compounds at $37^{\circ} \mathrm{C}$ in a humidified atmosphere containing $5 \% \mathrm{CO}_{2}$. Viable cells were counted under the microscope after 24 hours. The antimicrobial activities were measured according to Anke el al. [6].

The incorporation of $\left[2{ }^{14} \mathrm{C}\right]$ uridine $(1.96 \mathrm{GBq} / \mathrm{mMol})$, $\left[2-{ }^{14} \mathrm{C}\right]$ thymidine $(2 \mathrm{GBq} / \mathrm{mMol})$ and $\left[1-{ }^{14} \mathrm{C}\right]$ leucine ( $2 \mathrm{GBq} / \mathrm{mMol}$ ) into RNA, DNA and proteins was assayed as described previously [7] with slight modifications. Jurkat cells, $10^{5}$, in RPMI medium supplemented with $10 \%$ of fetal calf serum were incubated for 24 hours with $3700 \mathrm{~Bq}$ of the precursors, washed and the TCA-precipitates collected on nitrocellulose filters. After drying the radioactivity was measured by liquid scintillation counting.

\section{Results and Discussion}

The fermentation of Dasyscyphus niveus and the isolation of the dasyscyphins are described in the experimental section. The elucidation of the structure of niveulone is discussed in an accompanying paper [4] while the structures of the dasyscyphins will be described elsewhere [5].

\section{Biological Properties}

Dasyscyphin A (1) showed no effects in any of the biological assays discussed here. The antimicrobial activities of dasyscyphin B (2) and dasyscyphin C (3) are shown in Table 1. Compound $\mathbf{3}$ inhibited the growth of bacteria at concentrations between $5 \sim 100 \mu \mathrm{g} / \mathrm{ml}$ while antifungal properties were observed at the same concentrations. Compound $\mathbf{2}$ exhibits strong antifungal activity against Zygorhynchus moelleri, Absidia glauca (MIC $1 \mu \mathrm{g} / \mathrm{ml}$ ) and Nematospora coryli (MIC $5 \mu \mathrm{g} / \mathrm{ml}$ ). Niveulone (4) showed weak antifungal activity only against Nematospora coryli (MIC $80 \mu \mathrm{g} / \mathrm{ml}$ ).

While no cytotoxic activities of dasyscyphin A (1) were observed at concentrations up to $100 \mu \mathrm{g} / \mathrm{ml}$, dasyscyphin B (2) and dasyscyphin C (3) were highly cytotoxic towards Colo-320, HepG2, U937, Hela and Jurkat cells. The 
Table 1 Minimal inhibitory concentration (MIC) of dasyscyphin B (2) and dasyscyphin C (3) in the serial dilution assay

\begin{tabular}{|c|c|c|}
\hline \multirow{2}{*}{ Organism } & \multicolumn{2}{|c|}{$\mathrm{MIC}[\mu \mathrm{g} / \mathrm{ml}]$} \\
\hline & 2 & 3 \\
\hline \multicolumn{3}{|l|}{ Bacteria } \\
\hline Bacillus brevis & 100 & 100 \\
\hline Bacillus subtilis & 10 & 20 \\
\hline Corynebacterium islandicum & - & 5 \\
\hline Enterobacter dissolvens & - & - \\
\hline Micrococcus luteus & n.t & 5 \\
\hline Mycobacterium phlei & 5 & 5 \\
\hline \multicolumn{3}{|l|}{ Yeasts } \\
\hline Candida glabrata & - & - \\
\hline Candida krusei & - & - \\
\hline Candida Iusitaniae & n.t. & 100 \\
\hline Candida parapsilosis & - & - \\
\hline Nadsonia fulvescens & 5 & 50 \\
\hline Nematospora coryli & 5 & - \\
\hline Saccharomyces cerevisiae & - & - \\
\hline \multicolumn{3}{|l|}{ Filamentous fungi } \\
\hline Absidia glauca (+) & 1 & 50 \\
\hline Absidia glauca (-) & 1 & 100 \\
\hline Alternaria porri & 100 & 100 \\
\hline Ascochyta pisi & 100 & 20 \\
\hline Aspergillus ochraceus & 100 & 20 \\
\hline Fusarium fujikuroi & - & 100 \\
\hline Fusarium oxysporum & - & 100 \\
\hline Paecilomyces variotii & 100 & 50 \\
\hline Penicillium islandicum & 10 & 50 \\
\hline Penicillium notatum & 5 & 20 \\
\hline Zygorhynchus moelleri & 1 & 100 \\
\hline
\end{tabular}

— =no effects up to $100 \mu \mathrm{g} / \mathrm{ml}$.

cytotoxic properties of niveulone (4) were much less pronounced (Table 2).

The effects of $\mathbf{2}$ on protein, DNA and RNA syntheses of Jurkat cells are shown in the Fig. 2. The three macromolecule syntheses are inhibited with $\mathrm{IC}_{50}$ values $1.3 \mu \mathrm{g} / \mathrm{ml}$ (proteins, DNA) and $>3 \mu \mathrm{g} / \mathrm{ml}$ (RNA).

The structures of dasyscyphin B (2) and dasyscyphin C (3) bear some resemblance to the recently published new terpenes F-12436A and F-12436C both exhibiting antibiotic activities against methicillin-resistant Staphylococcus aureus and Enterococcus faecalis [1] and pelorol (5) which was isolated from the sponge Dactylospongia elegans [8] and later from Petrosaspongia metachromia [9]. Smenodiol (smenospongin) (6), a metabolite from a Seychellean sponge belonging to the
Table 2 Cytotoxic activities of dasyscyphin B (2), dasyscyphin C (3) and niveulone (4)

\begin{tabular}{lccc}
\hline & & & \\
Cell line & & $\mathbf{3}$ & \\
\cline { 2 - 4 } & $\mathbf{2}$ & $\mathbf{3} \mathrm{g} / \mathrm{ml}]$ & \\
\hline Colo 320 & 2 & 0.8 & $>20$ \\
HeLa S3 & 1 & 0.8 & $>20$ \\
Hep G2 & 3 & 0.9 & $>20$ \\
U 937 & 1 & 0.7 & 15 \\
Jurkat & 2 & 0.6 & 15 \\
\hline
\end{tabular}

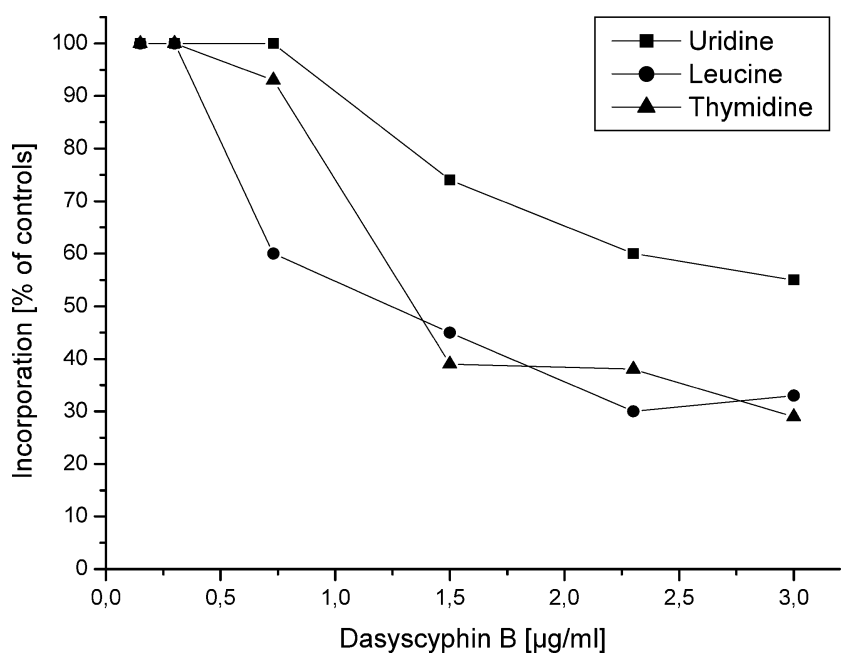

Fig. 2 Effects of dasyscyphin B (2) on protein, DNA and RNA syntheses in Jurkat cells.

Incorporation into the controls (100\%): $\left[2-{ }^{14} \mathrm{C}\right]$ thymidine (DNA), $1503 \mathrm{cpm}$; [2- $\left.{ }^{14} \mathrm{C}\right]$ uridine (RNA), $9217 \mathrm{cpm}$; $\left[1-{ }^{14} \mathrm{C}\right]$ leucine (proteins), $8465 \mathrm{cpm}$

genus Smenospongia could be considered a possible direct precursor thereof [10]. Pelorol has been described as an effective SH2-domain-containig inositol 5-phosphatase (SHIP) agonist. SHIP plays an important role in human disease like diabetes mellitus, leukemia, and others, and it is claimed to be an important potential therapeutic target [11].

Acknowledgements The Dasyscyphus niveus A0101 strain was kindly provided by Prof. H. Anke, IBWF Kaiserslautern.

\section{References}

1. Takahashi S, Hosoya T. New terpene compounds F-12436A, 
$\mathrm{B}$, and $\mathrm{C}$ of Dasyscyphella nivea having antibacterial activity. JP 0917609107.08 (1997)

2. Mierau V, Anke T, Sterner O. Two new biologically active cyclopentenones from Dasyscyphus sp. A47-98. J. Antibiot 57: 311-315 (2004)

3. Tanaka M, Nara F, Suzuki-Konagai K, Hosoya T, Ogita T. Structural elucidation of scyphostatin, an inhibitor of membrane-bound neutral sphingomyelinase. J Am Chem Soc 119: 7871-7872 (1997)

4. Rojas de la Parra V, Mierau V, Anke T, Sterner O. Niveulone, a heterocyclic spiro terpenoid from the ascomycete Dasyscyphus niveus. J. Antibiot, submitted

5. Rojas de la Parra V, Mierau V, Anke T, Sterner O. Cytotoxic terpenoids from Dasyscyphus niveus. Tetrahedron, in print

6. Anke H, Bergendorff O, Sterner O. Assays of the biological activities of guaiane sesquiterpenoids isolated from the fruit bodies of edible Lactarius species. Food Chem Toxicol 27: 393-397 (1989)

7. Filip P, Weber RWS, Sterner O, Anke T. Hormonemate, a new cytotoxic and apoptosis-inducing compound from the endophytic fungus Hormonema dematioides. I. Identification of the producing strain, and isolation and biological properties of hormonemate. Z Naturforsch 56c: 547-552 (2003)

8. Goclik E, Konig G M, Wright A D, Kaminsky R. Pelorol from the tropical marine sponge Dactylospongia elegans. J Nat Prod 63: 1150-1152 (2000)

9. Kwak JH, Schmitz FJ, Kelly M. Sesquiterpene quinols/quinones from the Micronesian sponge Petrosaspongia metachromia. J Nat Prod 63: 1153-1156 (2000)

10. Venkateswarlu Y, Faulkner DY. Smenochromenes, unusual macrocyclic sesquiterpene hydroquinone derivatives from a seychelles sponge of the genus Smenospongia. J Org Chem 56: 6271-6274 (1991)

11. Pendaries C, Tronchere H, Plantavid M, Payrastre B. Phosphoinositide signaling disorders in human diseases. FEBS Lett 546(1): 25-31 (2003) 